\title{
Treatment of high salt oxidized modified starch waste water using micro-electrolysis, two-phase anaerobic aerobic and electrolysis for reuse
}

\author{
Xuenong $\mathbf{Y i}^{1} \cdot$ Yulin Wang ${ }^{2}$
}

Received: 25 April 2014/Accepted: 25 July 2016/Published online: 24 August 2016

(c) The Author(s) 2016. This article is published with open access at Springerlink.com

\begin{abstract}
A combined process of micro-electrolysis, twophase anaerobic, aerobic and electrolysis was investigated for the treatment of oxidized modified starch wastewater (OMSW). Optimum ranges for important operating variables were experimentally determined and the treated water was tested for reuse in the production process of corn starch. The optimum hydraulic retention time (HRT) of micro-electrolysis, methanation reactor, aerobic process and electrolysis process were 5, 24, 12 and $3 \mathrm{~h}$, respectively. The addition of iron-carbon fillers to the acidification reactor was $200 \mathrm{mg} / \mathrm{L}$ while the best current density of electrolysis was $300 \mathrm{~A} / \mathrm{m}^{2}$. The biodegradability was improved from 0.12 to 0.34 by micro-electrolysis. The whole treatment was found to be effective with removal of $96 \%$ of the chemical oxygen demand (COD), $0.71 \mathrm{~L} /$ day of methane energy recovery. In addition, active chlorine production $(15,720 \mathrm{mg} / \mathrm{L})$ was obtained by electrolysis. The advantage of this hybrid process is that, through appropriate control of reaction conditions, effect from high concentration of salt on the treatment was avoided. Moreover, the process also produced the material needed in the production of oxidized starch while remaining emission-free and solved the problem of high process cost.
\end{abstract}

Yulin Wang

wangylynn@163.com

1 School of Environment and Architecture, University of Shanghai for Science and Technology, No. 516, Jungong Road, Yangpu District, Shanghai, China

2 Environment Protection Department, Shanghai Anyo Energy Efficiency Co., Ltd, No. 171, Garden Road, Hongkou District, Shanghai, China
Keywords High salt · Oxidized starch wastewater . Combined process $\cdot$ Reuse $\cdot$ Emission-free

\section{Introduction}

Industrial demand for modified starch triggers the rise in number and expanding in scale of starch factories. The modified starch processes generate wastewater containing organic and inorganic matters that affect wastewater treatment, especially in chemical modification such as oxidation. A large amount of $\mathrm{NaCl}$ was produced during the oxidized modified starch production processes in the wastewater (Chavalparit and Limpaseni 1995). This is because of the addition of chemical substances to the process and the adjustment of $\mathrm{pH}$ with $\mathrm{HCl}$. The presence of high salt concentration has been traditionally considered as inhibitory for biological wastewater treatment (Fusuwankaya et al. 2009; Kokabian et al. 2013) and caused paralysis of the original wastewater treatment system.

In recent days, studies on treatment of starch wastewater treatments mainly include flocculation and sedimentation, anaerobic biological treatment and aerobic biological process (Abeling and Seyfried 1993; Deng et al. 2003; Rajasimman and Karthikeyan 2007; Li et al. 2011). But there have been few cases on modified starch wastewater treatment, and those under investigation have considered neither the removal nor the reuse of salt generated. In one approach, an anaerobic hybrid reactor was used to treat the wastewater and its feasibility under high salt condition was proved but with no further discussion on salt removing (Fusuwankaya et al. 2009). In another approach, combined process of sedimentation, microfiltration and reverse osmosis was developed, but it only discussed the impact of 
high salt, and the cost was high, and utilization of resources was limited (Cancino-Madariaga and Aguirre 2001).

Considering the poor biodegradability, high salt concentration and complexity of oxidized modified starch wastewater, a combination process of micro electrolysis, two-phase anaerobic, aerobic and electrolysis was designed and a micro-electrolysis anaerobic two-phase reactor was developed. Effective control of the reaction conditions was necessary to avoid the inhibition of high salt to the processes. Hazardous materials and pollutants with poor biodegradability can be eliminated by the preset micro electrolysis (Huang et al. 2013) and the ratio of BOD/COD can be greatly improved so that microorganism activity is not restrained by hazardous materials in the wastewater $(\mathrm{Li}$ et al. 2010; Tao and Kang 2014). Other organic pollutants, ammonia nitrogen, and biodegradable pollutants can be removed by anaerobic and aerobic biological treatment (Abou-Elela et al. 2010; Shi et al. 2014). The remaining organics can be removed by electrolysis (Kim et al. 2013), and then active chlorine produced in the process can be reused in oxidized starch production process (Lin et al. 1998; Zaviska et al. 2012), as well as the treated water. This combination saves production process costs and maximizes resource utilization.

\section{Materials and methods}

\section{The source and quality of wastewater}

Table 1 is the original composition of oxidized starch wastewater obtained from a corn starch factory.

Figure 1 shows the flow chart of the combined process.

\section{Reactor}

A cylindrical-shaped reactor operated in a fed-batch mode as the micro-electrolysis anaerobic two-phase reactor is shown in Fig. 2. It had a working volume of $1.5 \mathrm{~L}$ and was divided into two laps. The volume ratio of inner to outer lap was 1:2. The inner lap was further divided into two along diameter. The left serves as a micro electrolysis reactor where iron-carbon fillers were placed, and the right

Table 1 Characteristics of OMSW process

\begin{tabular}{ll}
\hline Parameters & OMSW \\
\hline $\mathrm{COD}(\mathrm{mg} / \mathrm{L})$ & 8050 \\
$\mathrm{BOD}(\mathrm{mg} / \mathrm{L})$ & 966 \\
$\mathrm{NH}_{4}^{+}-\mathrm{N}(\mathrm{mg} / \mathrm{L})$ & $5-7$ \\
$\mathrm{Salinity}-\mathrm{NaCl}(\%)$ & 22 \\
$\mathrm{pH}$ & 3.9 \\
\hline
\end{tabular}

is an acidification reactor with five compartments, where iron-carbon fillers, as the biocarriers to enrich the biofacies, were also placed. The outer lap, as a methane reactor, has 12 compartments. Inside both the methane reactor and the acidification reactor were installed an inclined tube. The iron-carbon fillers had a surface area of $120 \mathrm{~m}^{2} / \mathrm{g}$, a porosity of $65 \%$, Fe content of $75 \%$, C content of $20 \%$ and the catalytic element of $5 \%$. Halophilic bacteria including acid-forming bacteria and methanogen were needed to be acclimated for anaerobic.

\section{Micro electrolysis, two-phase anaerobic and aerobic procedures}

Bacteria extracted in starch wastewater outfall was used for the biochemical procedure after halotolerancy improvement in the wastewater with gradually increasing salt concentration. The fluid was removed from the reactor in the middle and into the micro electrolysis reactor from the bottom. The volume ratio of solution to fillers was 1:1. Because of the high salinity, the raw wastewater worked as an electrolyte and promoted micro electrolysis (Tao and Kang 2014). After a certain time of mixing and reaction, the $\mathrm{pH}$ value was regulated to 8 with $\mathrm{NaOH}$. After sedimentation, the hydroxide precipitation was separated from the reaction system, and the supernatant overflowed into the up-flow and down-flow of the first interlayer in acidification reactor alternately at a HRT of 1-6 h. The methane reactor was between the two interlayers. And the second interlayer had a similar running mode with the first one at a HRT of 12-48 h. The inclined tube was in the up-flow area.

\section{Electrolytic experiments}

To avoid deposition on the electrode during the electrolysis, poly aluminium chloride (PAC) was added into the aerobically treated water for the purpose of removing microorganisms and suspended solids. The electrolysis experiments used titanium electrode coated with $\mathrm{RuO}_{2}$ (Ti$\mathrm{RuO}_{2}$ ) as anode and cathode with an effective surface area of $24 \mathrm{~cm}^{2}$ and the interval between electrode plates was $2 \mathrm{~cm}$. The test was conducted under room temperature in an installation which had a total working volume of $300 \mathrm{~mL} . \mathrm{H}_{2}$ f process was directly discharged and $\mathrm{Cl}_{2}$ was transferred into the electrolytes by air tube in favor of sodium hypochlorite generation.

\section{Analytical methods}

After the steady-state conditions were reached, the physicchemical analysis investigated covers the following parameters. COD was determined using the potassium 


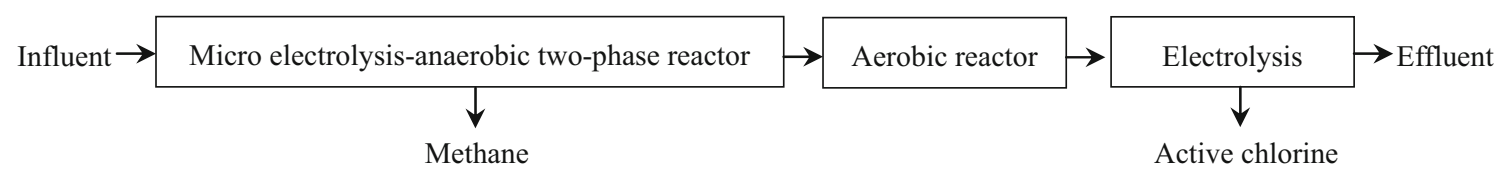

Fig. 1 Technological flow chart of the combination process

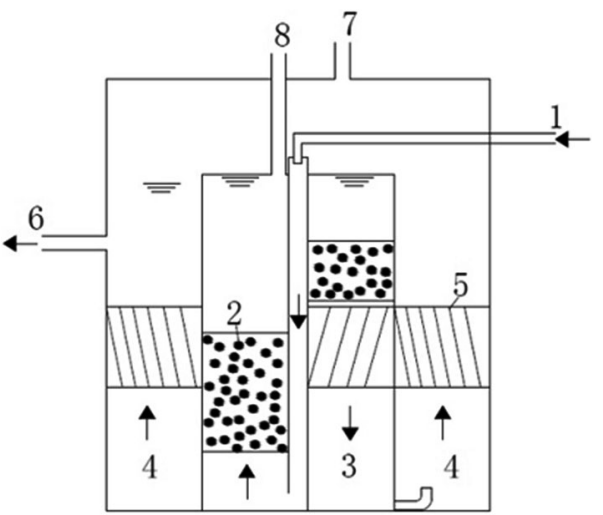

Fig. 2 Micro-electrolysis-anaerobic two-phase reactor. 1 inlet; 2 iron-carbon fillers; 3 acidification reactor; 4 methane reactor; 5 inclined tube; 6 outlet; 7 methane outlet; 8 sample connection for micro electrolysis effluent

dichromate method based on the Standard of the People's Republic of China for Environmental Protection (Zhang et al. 2006). Five-day biological oxygen demand $\left(\mathrm{BOD}_{5}\right)$ was measured by the respirometric method (WTW Oxitop ${ }^{\circledR}$ IS6, Germany). The methane production and $\mathrm{pH}$ values were daily determined. The biogas production was first passed through a bottle filled with $3 \% \mathrm{NaOH}$ solution to adsorb the $\mathrm{CO}_{2}, \mathrm{H}_{2} \mathrm{~S}$ and other trace amounts gas, and then the methane production was measured volumetrically using a wet gas flow meter (Sun et al. 2012). During the electrolysis process, the current density and temperature were monitored in real time. Chloride of the effluent was measured using argentometric method (APHA and AWWA 1998) and active chlorine was measured by iodometry (Lide 2012).

\section{Results and discussion}

\section{Optimum HRT of micro electrolysis}

The $\mathrm{pH}$ did not need to be adjusted, because the wastewater feed $\mathrm{pH}$ was 3.9 which was conducive to the micro electrolysis ( $\mathrm{Li}$ et al. 2010). When those fillers were in contact with wastewater, numerous microscopic galvanic cells formed between the iron and carbon (Qin et al. 2012). The reactions can be represented as:

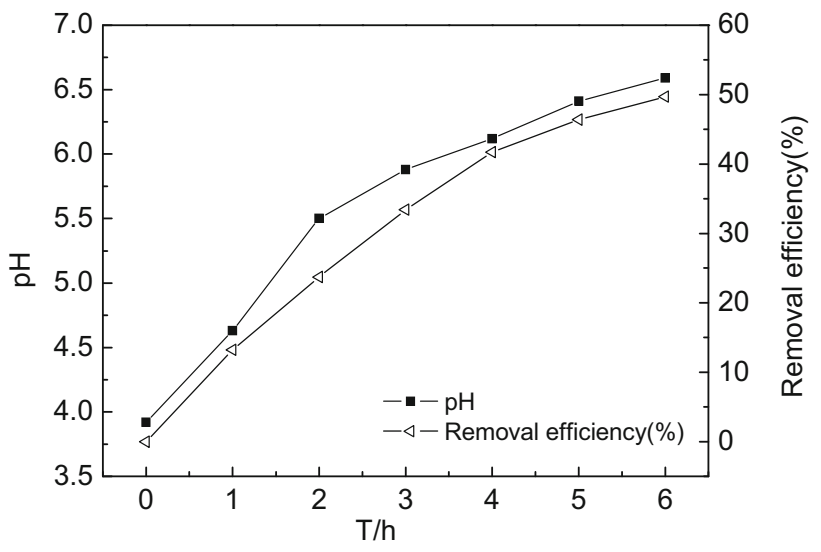

Fig. 3 Changes of $\mathrm{pH}$ and removal efficiency of COD by microelectrolysis

Iron anode (oxidation):

$\mathrm{Fe} \rightarrow \mathrm{Fe}^{2+}+2 \mathrm{e}$

$\mathrm{Fe}^{2+} \rightarrow \mathrm{Fe}^{3+}+\mathrm{e}$

Carbon cathode (reduction) in the presence of oxygen:

$2 \mathrm{H}^{+}+2 \mathrm{e} \rightarrow 2[\mathrm{H}] \rightarrow \mathrm{H}_{2}$

$\mathrm{O}_{2}+2 \mathrm{H}_{2} \mathrm{O}+4 \mathrm{e} \rightarrow 2 \mathrm{OH}^{-}$

$\mathrm{Fe}^{2+}$ and $[\mathrm{H}]$ generated during micro-electrolysis have high chemical activity (Lai et al. 2012) and are believed to break down the carbon chains of organic contaminants. As shown in Fig. 3, the reaction times were 1, 2, 3, 4, 5 and $6 \mathrm{~h}$, removing COD of 13.2, 24.7, 33.4, 42.7, 46.4 and $49.1 \%$, respectively. From the 4th hour, COD removal showed down as the increase in $\mathrm{pH}$ value retards the reaction rate of micro electrolysis. As HRT is too long, since the biopolymers in the reactor contained large amount of anion groups such as $\mathrm{OH}^{-}, \mathrm{CO}_{3}{ }^{2-}$ and other negatives groups, the iron ions could easily precipitate in term of $\mathrm{Fe}(\mathrm{OH})_{\mathrm{X}}$. They can cover the surface of ironcarbon fillers, and inhibit the process of micro electrolysis. To ensure good results on COD removing under neutral environment during the subsequent biological treatment and minimize the loss of fillers, the optimal reaction time was determined as $5 \mathrm{~h}$. 


\section{Improvement of wastewater biodegradability by micro electrolysis}

The ratio of $\mathrm{BOD} / \mathrm{COD}$ was measured as a representation of biodegradability. The detection values of micro-electrolysis effluent were shown in Fig. 4. The water samples of inner reactor were replaced every $5 \mathrm{~h}$ for batch tests. The value of COD for seven batch tests dropped from $8050 \mathrm{mg} / \mathrm{L}$ to $4428.6,4506.3,4410.2,4379.8,4398.4$, 4296.5 and $4403.8 \mathrm{mg} / \mathrm{L}$, respectively. The BOD/COD ratio of wastewater changed from 0.12 to 0.34 , indicating that those poorly biodegradable pollutants became easily biodegradable and toxic substances became less toxic after micro electrolysis treatment. This also provided a foundation for the follow-up bioprocess.

\section{Influence of dosage of iron-carbon fillers in the acidification reactor}

COD changes of the anaerobic effluent under different dosage at 0, 100, 200 and $300 \mathrm{mg} / \mathrm{L}$ were shown in Fig. 5 . The COD removal efficiency were 28.2, 34.9, 43.5 and $42 \%$. When dosage of iron-carbon fillers was $100 \mathrm{mg} / \mathrm{L}$, compared with no added fillers, the removal efficiency increased by about $1 / 4$, indicating that the presence of ironcarbon fillers strengthens the anaerobic treatment. Iron could improve the degradability of anaerobic sludge, because iron could lower the solution oxidation-reduction potential beneficial to anaerobic organism and could be oxidized to $\mathrm{Fe}^{2+}$ and $\mathrm{Fe}^{3+}$ which were the necessary elements for anaerobic microorganism (Zhang et al. 2007), and some anaerobic organism could also accelerated the corrosion of iron (Duan et al. 2008). That was a possible reason for the improved COD removal at $100 \mathrm{mg} / \mathrm{L}$ dosage. And when the dosage was $200 \mathrm{mg} / \mathrm{L}$, the removal efficiency of COD reached the highest value.

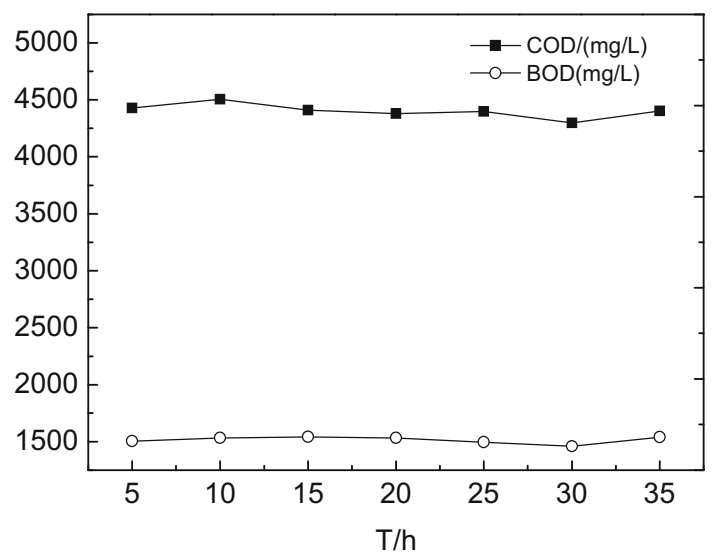

Fig. 4 The ratio of BOD/COD of micro-electrolysis effluent for seven batch tests

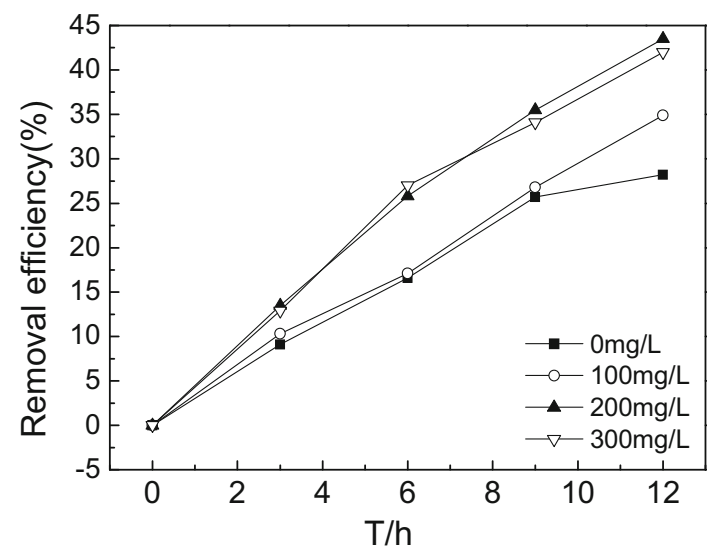

Fig. 5 COD removal efficiency of the anaerobic effluent at various dosage of iron-carbon fillers

\section{Optimization of HRT in the methane reactor}

In this study, a reactor was used as the micro-electrolysisanaerobic two-phase reactor with the inner lap designed as micro electrolysis and acidification reactor and the outer as a two-phase anaerobic reactor. Two parts of acidogenic phase and methanogenic phase separated in the reactor, which could ensure the acid-forming bacteria and methanogenic bacteria functioning in their corresponding circumstances. The sludge sedimentation in the inclined tube did not only effectively reduce the loss of sludge, but also formed a layer of suspended sludge at the base so that sludge concentration improved. The water operated continually. The HRT at acidification reactor was similar with the micro-electrolysis reactor. At the optimal conditions of previous process, the effect of HRT (HRT in the methane reactor) on the removal efficiencies of COD was investigated. As shown in the Fig. 6, the COD removal efficiency were $40,60.1,60.2,60.5 \%$ respectively, at the HRT of 12 , 24, 36 and $48 \mathrm{~h}$, accordingly. Organic pollutants cannot be adequately degraded at a short HRT, but too long HRT caused self-degradation of microorganisms. It's clear that HRT at $24 \mathrm{~h}$ is recommended for the reactor.

\section{The methane gas yield during anaerobic process}

To investigate the effect of $\mathrm{Fe}^{2+}$ and $\mathrm{Fe}^{3+}$ on the anaerobic performance, a micro-electrolysis anaerobic two-phase reactor (R1) and its control reactor (R2) were operated in parallel. There were no iron fillers in R2. Collection of methane gas from the micro-electrolysis anaerobic twophase reactor started when the reactor had started up for 10 days. As shown in the Fig. 7, at a influent COD concentration of $1500 \mathrm{mg} / \mathrm{L}$ from 1 st day to 7 th day, the methane production in the two reactors were $0.71 \pm$ $0.19 \mathrm{~L} / \mathrm{d}(\mathrm{R} 1)$ and $0.32 \pm 0.11 \mathrm{~L} / \mathrm{d}(\mathrm{R} 2)$. According to the 


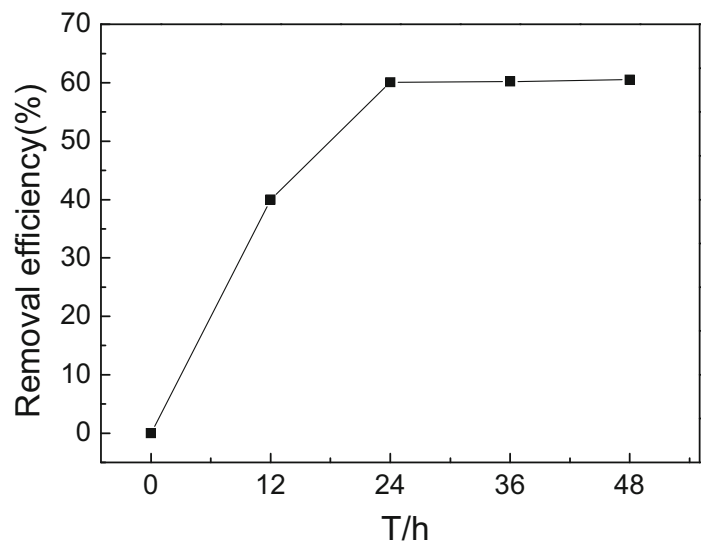

Fig. 6 COD removal efficiency at different HRT of the methane reactor

calculation based on the theoretical methane production of $0.35 \mathrm{~mL} / \mathrm{mg}$ COD removed at standard state (Toprak 1995), the methane production efficiency (methane COD/ removed COD) were 79.8 and $36.0 \%$ in the $\mathrm{R} 1$ and $\mathrm{R} 2$. This result indicated that the addition of $\mathrm{Fe}^{\mathrm{x}+}$ in $\mathrm{R} 1$ increased methane production by two times compared with $\mathrm{R} 2$, which was in agreement with the report of Coates et al. (2005) who demonstrated that stimulated microbial $\mathrm{Fe}^{3+}$ reduction can enhance methane production. For the idea of zero emissions and the maximization of utility in resource, the methane gas can be collected for recycling and generating economic effects.

\section{Optimization of HRT in the aerobic reactor}

Anaerobic affluently moved into the aerobic reactor, the COD variation of aerobic effluent is shown in Fig. 8. The effluent COD removal significantly reduced in the aerobic process within $12 \mathrm{~h}$ and reached to $40.9 \%$ at $12 \mathrm{~h}$. After

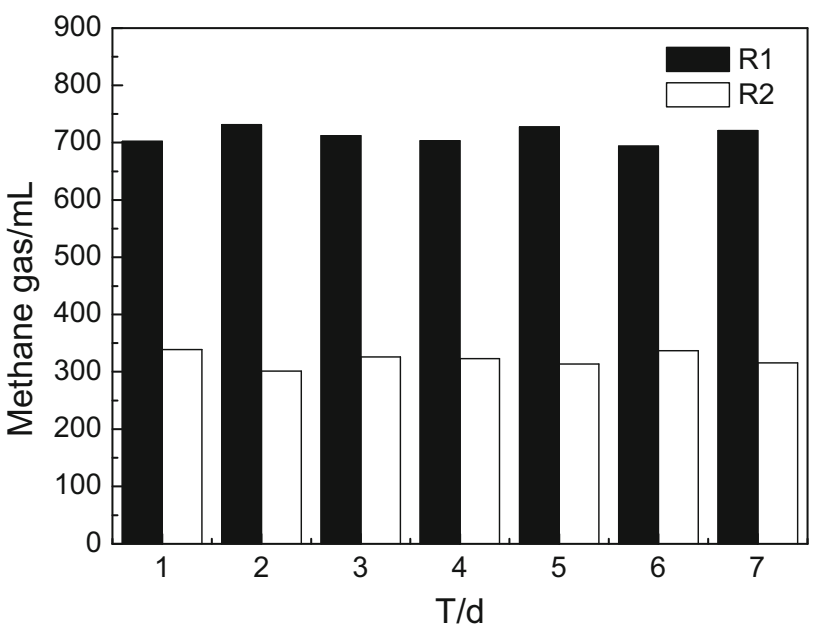

Fig. 7 Methane gas yield in the two reactors (R1, R2)
$12 \mathrm{~h}$, the decreasing trend of COD was not obvious. So the optimal HRT of $12 \mathrm{~h}$ was determined.

\section{Influence of current density during electrolysis}

The reaction was running under the current density of 200 , 300 and $400 \mathrm{~A} / \mathrm{m}^{2}$ for the aerobic treated effluent. The explanation of why the initial $\mathrm{pH}$ of feed less than 7 was that PAC was added into the effluent of aerobic to remove microorganisms.

After the electrolysis process performed for $3 \mathrm{~h}$, the COD removal efficiency significantly were 36,73 and $78 \%$, as shown in Fig. 9. It was probably because $\mathrm{Cl}^{-}$ions in the water turned into active chlorine in the electric field, resulting in direct degradation of organic pollutants. The removal rate proved that with the increase of current density, electrolysis process effect was improved naturally. During the test, the water samples would be heated as the reaction progress and the temperature rose quickly at current density of $400 \mathrm{~A} / \mathrm{m}^{2}$. To make efficient use of energy, the optimum current density was designed as $300 \mathrm{~A} / \mathrm{m}^{2}$, and all subsequent trials selected this density.

Salt content in wastewater was high so that sodium hypochlorite and [O], which had strong oxidizing with organic matters (Zhou et al. 2014), were produced by electrolysis of salt. Then the organic matters were degraded by electrolysis process. The mechanism displays as follows.

Electrode reaction:

$2 \mathrm{Cl}^{-} \rightarrow \mathrm{Cl}_{2}+2 \mathrm{e}$

$2 \mathrm{H}^{+}+2 \mathrm{e} \rightarrow \mathrm{H}_{2}$

$2 \mathrm{NaOH}+\mathrm{Cl}_{2} \rightarrow \mathrm{NaCl}+\mathrm{NaClO}+\mathrm{H}_{2}$

$\mathrm{ClO}^{-} \rightarrow \mathrm{Cl}^{-}+[\mathrm{O}]$

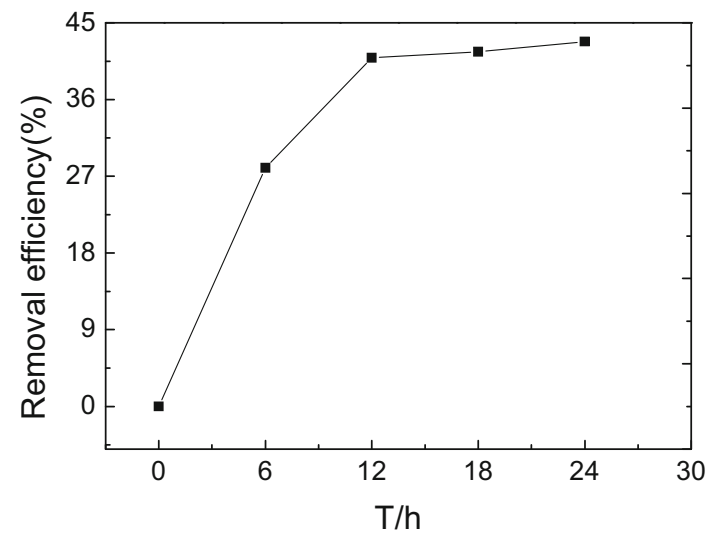

Fig. 8 Removal efficiency of COD at different HRT of the aerobic reactor 


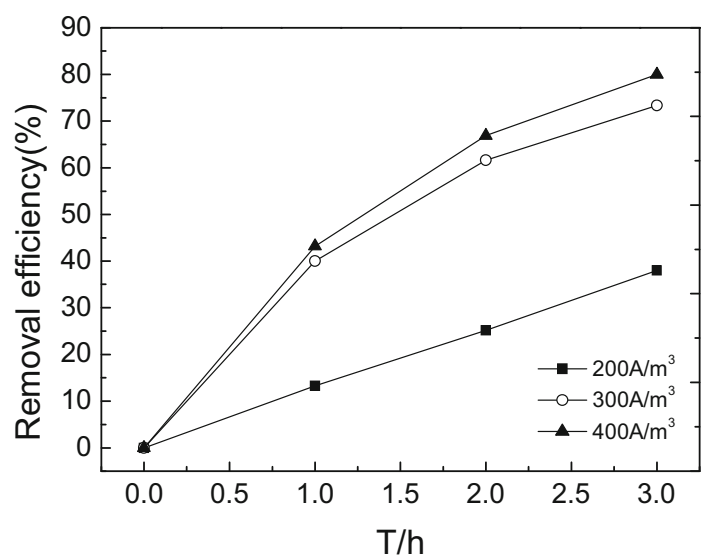

Fig. 9 Removal efficiency of COD at different current density

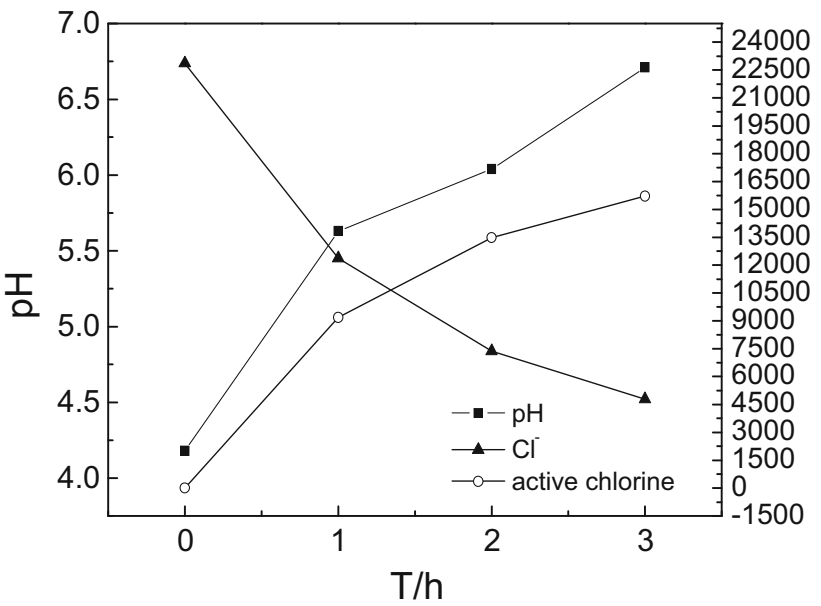

Fig. 10 The concentration of chlorine ions and available chlorine

$\mathrm{ClO}^{-}+2 \mathrm{H}^{+}+2 \mathrm{e} \rightarrow \mathrm{Cl}^{-}+\mathrm{H}_{2} \mathrm{O}$

The concentration of chlorine ions and available chlorine were shown in Fig. 10. In fact, during electrolysis, $\mathrm{pH}$ value of the electrolyzed-solution increases due to the production of hydroxide ions at the cathode electrode. The concentration of chloride ion decreased from $22,855.5$ to $4787.6 \mathrm{mg} / \mathrm{L}$ and active chlorine rose to $15,719 \mathrm{mg} / \mathrm{L}$. Theoretical yield based on the reaction formula of active chlorine showed that, the remaining available chlorine concentration accounted for $60 \%$ of the theoretical yield. Considering the incomplete conversion factors and 30-40\% active chlorine in the electrolysis process involved in the degradation of organic matters, both production of sodium hypochlorite and degradation of organic matters reacted in the electrolytic process. Residual chlorine in water samples could be collected after treatment and reused.
Table 2 Effluent quality

\begin{tabular}{ll}
\hline Parameters & Value \\
\hline $\mathrm{COD}(\mathrm{mg} / \mathrm{L})$ & 220 \\
$\mathrm{Cl}^{-}(\mathrm{mg} / \mathrm{L})$ & 4790 \\
Active chlorine (mg/L) & 15,720 \\
$\mathrm{pH}$ & 6.8 \\
\hline
\end{tabular}

Table 3 The quality testing of oxidized starch

\begin{tabular}{lll}
\hline$(\%)$ & Value & Standard \\
\hline Starch content & 93 & $\geq 85$ \\
Water & 9 & $\leq 12.5$ \\
Acidity & 15 & $\leq 18$ \\
Ash content & 0.03 & $\leq 0.1$ \\
Fiber & 0.09 & $\leq 0.5$ \\
Protein & 0.2 & $\leq 0.4$ \\
$\mathrm{SO}_{2}$ & 0.0009 & $\leq 0.004$ \\
Fats & 0.02 & $\leq 0.05$ \\
Fineness & 99.7 & $\geq 99.5$ \\
\hline
\end{tabular}

\section{Reuse of treated water}

This study treated oxidized modified starch wastewater with high salt by micro electrolysis, two-phase anaerobic, aerobic and electrolysis. The treated effluent quality was shown in Table 2.

The treated water by this treatment was used in the production process of corn starch. The quality tests for the production were shown in Table 3.

Because of the lack of sodium hypochlorite in the treated water, the productive process needs appropriate amount to add. But the added amount was far less than the amount in the previous production. As apparently seen from Table 3, it successfully applied the treated water to the production, and the oxidized starch product quality testing standards can be achieved.

\section{Conclusions}

Water quality was greatly improved and effectively reused in the production process of modified starch after the compound process of micro-electrolysis, two-phase anaerobic, aerobic and electrolysis. Thus, we can conclude that the combined process was an effective method to improve water quality of oxidized modified starch wastewater with high salt concentration. The removal rate of COD was $97.3 \%$ in the whole process. 
Micro electrolysis is a feasible method for the treatment and remediation of wastewater with high salt. After pretreatment, the removal efficiency of COD reached $46 \%$, and the ratio of BOD/COD in the effluent increased from 0.12 to 0.34 , which provided a good foundation for the follow-up bioprocess. The arrangement of iron-carbon fillers reinforced the effect of anaerobic treatment at a best dosage of $200 \mathrm{mg} / \mathrm{L}$.

The optimum hydraulic retention time of micro-electrolysis and acidification reactor, methane reactor and aerobic process were 5, 24 and $12 \mathrm{~h}$, respectively. The most effective current density of electrolysis was $300 \mathrm{~A} / \mathrm{m}^{2}$ with reaction time of $3 \mathrm{~h}$. The removal rates of COD in anaerobic process, aerobic treatment and electrolysis process were $45,62,40,70 \%$, respectively.

The additional $\mathrm{Fe}^{\mathrm{x}+}$ enhance methane production and $0.71 \mathrm{~L} /$ day methane gas was collected from anaerobic biological process. Moreover, 15,800 mg/L active chlorine was produced by electrolytic process. These resources can be recycled to produce economic benefits.

Open Access This article is distributed under the terms of the Creative Commons Attribution 4.0 International License (http:// creativecommons.org/licenses/by/4.0/), which permits unrestricted use, distribution, and reproduction in any medium, provided you give appropriate credit to the original author(s) and the source, provide a link to the Creative Commons license, and indicate if changes were made.

\section{References}

Abeling U, Seyfried CF (1993) Anaerobic-aerobic treatment of potato-starch wastewater. Water Sci Technol 28(2):165-176

Abou-Elela SI, Kamel MM, Fawzy ME (2010) Biological treatment of saline wastewater using a salt-tolerant microorganism. Desalination 250(1): 1-5

APHA, AWWA (1998) Standard methods for the examination of water and waste water, 20th edn. WPCF, New York

Cancino-Madariaga B, Aguirre J (2001) Combination treatment of corn starch wastewater by sedimentation, microfiltration and reverse osmosis. Desalination 279(1):285-290

Chavalparit O, Limpaseni W (1995) Pollutant load from modified starch factories in Thailand. The Engineering Institute of Thailand Under HM The King's Patronage (EIT), Annual Conference 77-89

Coates JD, Cole KA, Michaelidou U et al (2005) Biological control of hog waste odor through stimulated microbial Fe(III) reduction. Appl Environ Microbiol 71(8):4728-4735

Deng S, Bai R, Hu X et al (2003) Characteristics of a bioflocculant produced by Bacillus mucilaginosus and its use in starch wastewater treatment. Appl Microbiol Biotechnol 60(5):588-593

Duan J, Wu S, Zhang X et al (2008) Corrosion of carbon steel influenced by anaerobic biofilm in natural seawater. Electrochem Acta 54(1):22-28
Fusuwankaya K, Chaiprasert P, Suraraksa B (2009) Treatment of modified starch wastewater with high sodium chloride $(\mathrm{NaCl})$ concentration using an anaerobic hybrid reactor. Desalin Water Treat 4(1-3):224-228

Huang L, Sun G, Yang T et al (2013) A preliminary study of anaerobic treatment coupled with micro-electrolysis for anthraquinone dye wastewater. Desalination 309:91-96

Kim DG, Kim WY, Yun CY et al (2013) Agro-industrial wastewater treatment by electrolysis technology. Int $\mathrm{J}$ Electrochem Sci 8(7):9835-9850

Kokabian B, Bonakdarpour B, Fazel S (2013) The effect of salt on the performance and characteristics of a combined anaerobicaerobic biological process for the treatment of synthetic wastewaters containing Reactive Black 5. Chem Eng J 221:363-372

Lai B, Zhou Y, Yang P (2012) Passivation of sponge iron and GAC in $\mathrm{Fe}$ 0/GAC mixed-potential corrosion reactor. Ind Eng Chem Res 51(22):7777-7785

Li G, Guo S, Li F (2010) Treatment of oilfield produced water by anaerobic process coupled with micro-electrolysis. J Environ Sci 22(12): $1875-1882$

Li G, Ma X, Tu J (2011) Treatment of starch wastewater using UASB reactor with hydraulic circulation and biomass screen. Water Resource and Environmental Protection (ISWREP), 2011 International Symposium IEEE 2:834-837

Lide DR (ed) (2012) CRC handbook of chemistry and physics. CRC Press, Boca Raton

Lin SH, Shyu CT, Sun MC (1998) Saline wastewater treatment by electrochemical method. Water Res 32(4):1059-1066

Qin L, Zhang G, Meng Q et al (2012) Enhanced MBR by internal micro-electrolysis for degradation of anthraquinone dye wastewater. Chem Eng J 210:575-584

Rajasimman M, Karthikeyan C (2007) Aerobic digestion of starch wastewater in a fluidized bed bioreactor with low density biomass support. J Hazard Mater 143(1):82-86

Shi X, Lefebvre O, Ng KK et al (2014) Sequential anaerobic-aerobic treatment of pharmaceutical wastewater with high salinity. Bioresour Technol 153:79-86

Sun L, Wan S, Yu Z et al (2012) Anaerobic biological treatment of high strength cassava starch wastewater in a new type up-flow multistage anaerobic reactor. Bioresour Technol 104:280-288

Tao M, Kang TT (2014) Experimental study on high salt acid pretreatment of refinery wastewater. Adv Mater Res 859:369-372

Toprak H (1995) Temperature and organic loading dependency of methane and carbon dioxide emission rates of a full-scale anaerobic waste stabilization pond. Water Res 29(4):1111-1119

Zaviska F, Drogui P, Pablo G (2012) Statistical optimization of active chlorine production from a synthetic saline effluent by electrolysis. Desalination 296:16-23

Zhang H, Zhang D, Zhou J (2006) Removal of COD from landfill leachate by electro-Fenton method. J Hazard Mater 135(1):106-111

Zhang W, Chen L, Chen H, Xia SQ (2007) The effect of $\mathrm{Fe} 0 / \mathrm{Fe}^{2+}$ / $\mathrm{Fe}^{3+}$ on nitrobenzene degradation in the anaerobic sludge. Hazard Mater 143:57-64

Zhou Z, Hu DL, Zhang CQ et al (2014) Study on treatment of ammonium nitrogen in desulfurization and denitrification wastewater with sodium hypochlorite. Adv Mater Res 864:438-441 